DOI: $10.17516 / 1997-1370-0606$

УДК 394

\title{
Routes of Sustenance: Infrastructure and Food Security Strategies in Chukotka
}

\author{
Vladimir N. Davydov* and Elena A. Davydova \\ Peter the Great Museum of Anthropology \\ and Ethnography (Kunstkamera) RAS \\ St. Petersburg, Russian Federation
}

Received 10.03.2020, received in revised form 30.04.2020, accepted 12.05.2020

\begin{abstract}
The problem of food supply is especially poignant in the remote and hard to reach Arctic settlements. Therefore, local people have to develop their own food distribution strategies. They actively employ the alternative ways of food acquisition and accumulation to maintain a sense of their food security via the use of local infrastructure, networks of relatives and friends and technologies for self-production, processing and storage of products. The article describes the recent trends in food circulation in the Iul'tinskii district of the Chukotka Autonomous Okrug. The authors consider the existing model of food redistribution between the tundra camps, reindeer herding and coastal villages, as well as the district center. They analyze the impact that one of the largest Soviet projects in Chukotka - the Iul'tinskaia road had on food security practices of the local people. The emergence of new infrastructure has affected both their mobility and perception of food. The article demonstrates how a whole set of various state projects and commercial initiatives frame local nutritional needs, but at the same time can either hinder or contribute to their satisfaction. The relations between the infrastructural projects and the basic needs have both intersection points and "gaps" which require active regulation both by the members of the local community and the state. In this context, local people can be seen as the active agents who creatively use the existing in the region infrastructure in order to maintain their food security.
\end{abstract}

Keywords: Arctic, Chukotka, infrastructure, food security, autonomy, resources, supply, anthropology of food, mobility, reindeer herding.

The present research has been supported by the grant of the Russian Science Foundation (No. 19-78-10002), project "Food in the Russian Arctic: resources, technologies and innovations".

Research area: ethnography, ethnology and anthropology.

\footnotetext{
(C) Siberian Federal University. All rights reserved

* Corresponding author E-mail address: davydov.kunstkamera@gmail.com ORCID: 0000-0003-2738-4609 (Davydov); 0000-0002-9299-7551 (Davydova)
} 
Citation: Davydov, V.N., Davydova, E.A. (2020). Routes of sustenance: infrastructure and food security strategies in Chukotka. J. Sib. Fed. Univ. Humanit. Soc. Sci., 13(5), 772-782. DOI: 10.17516/19971370-0606.

\section{Introduction}

The socio-economic problems of the Russian northern regions are in the focus of the attention of both scientists and politicians. Recently the issues related to infrastructure, workplaces, and climate change have increasingly become the objects of study for sociologists, historians, ethnographers, anthropologists and other specialists. However, food supply - one of the basic domains of human life in the Arctic and the important criterion of local people's wellbeing in the remote regions, still remains the unresearched area.

During a six-month field research, which took place in the Iul'tinskii district of the Chukotka Autonomous Okrug from 2017 to 2019, we found out that the most pressing problem for local people was food supply of the native settlements and reindeer herders' camps in the tundra. The existing range of products definitely does not satisfy all the nutritional needs of local people. Therefore, they use the alternative and often invisible, from the point of view of an external observer, ways of acquiring and accumulating food resources. This article aims to analyze the contemporary trends in circulation of products in the Iul'tinskii district in Chukotka.

We will be focused on one of the largest Soviet projects in the region - the Iul'tinskaia road. This is a $207 \mathrm{~km}$ long highway connecting the seaport of Egvekinot on the coast of the Bering Sea with the continental part of the Iul'tinskii district of the Chukotka Autonomous Okrug. The prisoners of Chukotstroilag had being built the road from 1946 to 1951. It was the easternmost road of the Soviet Union and people used it year-round to reach local tin-tungsten deposits and maintain the work of the Iul'tin mining and processing plant. Nowadays local people employ this road to conduct everyday tasks and sustain a regular food supply. The road serves both as a "transport artery" and a resource for acquiring material objects and building materials. It does not only facilitate mobility but also changes the perception of food by local inhabitants.

\section{Anthropology of food: \\ supply in the Far North}

Anthropology of food has a long history; a huge amount of literature has been written on food and nutrition in different parts of the world (Mintz, Bois, 2002: 99-119). However, food practices rarely became the main focus of research until the 1970s (De Garine, 2004: 16). Modern investigations cover a wide range of issues connected with the relationship between people and food in global context: identity, memory, power, colonialism, ritual, exchange, feelings, etc. (Holtzman, 2006: 361-378, Sutton, 2010: 209-223, Yamin-Pasternak et al., 2014: 619-646, 2017: 117-136). It should be noted that scientists have been interested in this field since the formation of the anthropology/ethnography as a discipline. The classical works, based on the field data gathered in Chukotka, had the character of detailed ethnographic descriptions and researched food patterns of particular local groups (Bogoraz, 1991: 126-142, Vdovin, 1965).

It should be emphasized that in the 19th and the first half of the 20th century anthropologists studied local food systems and investigated how autonomous economic systems functioned. Gradually the interest of anthropologists shifted to the research of food practices in larger and more complex societies (Chatwin, 1997, Goody, 1998, Lentz, 1999, Lockwood, Lockwood, 2000, Mayer, 1996, Matossian, 1989). Since the second half of the 20th century the researchers incorporated the topic of food to build various theories (Levi-Strauss, 1969, Douglas 1966, 1972, Mintz, 1985, 1996). The turning point was the work of J. Goody (1982), revealing the connection between food systems and socio-economic structures. Since that time the anthropological study of food has been developed sufficiently to become a tool for studying various theoretical and methodological issues. However, despite the important 
contribution to anthropological theories, the researchers did not pay significant attention to food supply in the northern regions.

The problem of sustainable food supply is especially poignant in many Arctic settlements. Products are frequently overdue, have low quality and cost too much. Associated with the Arctic regions, "remoteness" is a relative and external category and it often serves as an object of manipulations. The Iul'tinskaia road in Chukotka provides the access to Amguema native village and functions as a main direction of food transportation. It makes the village accessible, but at the same time it does not mean that Amguema benefits from distance reduction to district center in the context of food supply. This closeness creates the possibility to deliver overdue products to the rural stores.

The processes and institutions of the global economic system, including the offshore economy have a serious impact on the life of local communities (Urry, 2014). Mechanisms of informal economy regulate food supply in Chukotka. Thus, the idiom of "remoteness" creates a scarcity in supply that gives the possibility to sell the low quality and overdue products. At the same time the products produced locally are often absent in the local shops. For instance, local fish and venison can be rarely bought in the stores of Egvekinot and native villages. Therefore, local people have to develop their own food security strategies. The distribution of low quality and overdue products in the "remote" places motivates them use the alternative ways of food supply and accumulation to maintain a sense of food security. People actively use the existing infrastructure, local friends' and relatives' networks as well as particular technologies for self-production, processing and storage of food. Local inhabitants are very creative and actively experiment in this field.

The article aims to answer the following questions: How do residents of the remote northern settlements independently maintain a sense of their food security at the local communities' microlevel? How do people in Chukotka, under the conditions of "weak" and irregular supplies, acquire the acceptable food resources for themselves? What kind of strategies of food storage and accumulation do they employ? To find the answers we will analyze various aspects of food supply practices in the native village of Amguema. First, we will identify local food distribution networks that exist both within a particular community and beyond. In this context it is important to pay attention to the materiality of food and track "cultural biography" (Kopytoff, 1986) of products within their movements and to the knowledge of the local community about its specific characteristics. Second, we will describe the impact of larger structures on food practices in the local communities: state, private trading companies, the global market economy. In particular, we will identify the role of the infrastructure in transportation and distribution of products. Third, we will observe how it affects the technologies of food preservation and cooking. Finally, we will pay attention to the process of how the infrastructure changes food aesthetics and local people's sensory perception of products (Yamin-Pasternak et al., 2014).

\section{Food routes: two-way traffic}

Local people are the active agents of food transportation. Their movements often imply the mobility of food between different locations. This mobility, as a rule, has a systematic character. Food supply means the functioning of particular mobility channels (Urry, 2012a; 2012b). Products continuously circulate between the reindeer herders' camps in tundra, coastal and inland settlements and the district center Egvekinot.

Any society has a tendency for domination of a certain circulation process, it has structured routes along which people, objects move and transmit the information (Urry, 2012a: 143). This process also characterizes food circulation between different localities. Meat is the main food at the traditional feasts of the Amguema Chukchis (Kuznetsova, 1957: 272). New feasts had appeared rather recently, such as the International Day of Indigenous People, celebrated on August 9th. People organize them in settlements and demonstrate Chukchi cuisine, that requires the transportation of products from the tundra to the village and the regional center. From the tundra people 
bring dried and fermented meat, herbs, berries and other products. In many respects, the food transportation became possible due to building and maintenance of the Iul'tinskaia road, which serves as the main mobility channel in the region and the route for food supply of native villages and reindeer herders' camps.

The local reindeer herding enterprise "Amguema" constantly supplies the camps in the tundra with the basic products. However, the delays and interruptions may take place due to breakdown of equipment, weather and products scarcity. The range of products supplied by the enterprise is often limited. In order to achieve the necessary products, reindeer herders order them by a radio set or a satellite phone. In this case their friends and relatives deliver food on private transport - cars or snowmobiles. In many cases reindeer herders can make pendulum movements to the village or Egvekinot on their own vehicles to purchase the necessary goods.

Until now we can find a parallel with the mutual exchange of reindeer and coastal Chukchis, which functioned in earlier times (Bogoras, 1904: 53, Krupnik, 2000: 50). Reindeer herders and coastal sea mammal hunters had various diets (Afanas'eva, Simchenko, 1993). Like these two groups, people living in the village and reindeer herders - groups, located in different places and having access to different resources, cooperate to obtain a variety of tastes and maintain a feeling of their food security. This system of food circulation also includes Egvekinot - the district center where these people periodically buy products. In Egvekinot, the choice of goods is bigger, products can be fresher and are sometimes sold cheaper. Reindeer herders, in turn, bring meat, fish and other produced products to supply their relatives, who live in the district center.

People transport food in two main directions. Therefore, when we speak about mobility of food in the 'remote regions', it means that people move material objects in two ways. Obvious is the fact that objects move with the mobility of people (Urry, 2012b: 98). Moreover, food supply is often the reason of these movements. Some places serve as hubs coordinating the mobility of various products and the plac- es for food exchange. Reindeer herders' camps function as locations where people distribute food. People constantly move between villages, the regional center and reindeer herders' camps in the tundra, and take food with them.

Another route of food transportation is Egvekinot - Amguema - Nutepel'men / Vankarem. Vankarem and Nutepel'men are the coastal villages. Residents of these settlements take venison in reindeer herders' brigades, which approach the coast with herds. They may exchange products from the local store and seal meat and fish to venison. They also may export the products of sea hunting for sale to Amguema, Egvekinot and sometimes to Anadyr. Basically, they exchange and sell fish, fat and meat of marine animals, including whale fat, walrus fermented meat and fat (kopal'khen).

Thus, the remote villages are not just the passive recipients of the external food supply, they create their own products such as venison, sea mammals' meat or fat, fish and local plants which often move the other way. The supply should not be seen as one direction process. As we have seen, food mobility between different points in Chukotka always takes place in two ways. Therefore, food security in this region is a result of the activities of the members of the whole local community. Continuous food redistribution helps people avoid the situation of food scarcity in numerous locations where they perform their daily tasks.

The described food circulation system is largely possible due to existence of the Iul'tinskaia road, which is actively used by local people and provides most of the movements in the area. The road significantly reduces the way from reindeer herders' camps and coastal villages to Amguema and district center. It provides the opportunity for food transportation in the region and makes it rather sustainable.

\section{Refrigerators and greenhouses: vernacular food security strategies}

Local people imply the use of a set of food security strategies. This helps them to avoid the lack of food supply in cases of force-major situations. They use different strategies to maintain particular food autonomy regime (Davydova, Davydov, 2018). For instance, peo- 
ple tend to increase the number of refrigerators to store products. At the same time, they became more dependent on the external electric energy supply. In comparison, the idea of autonomation, which is central to a strategy of self-isolation during the increasing of the risks of coronavirus (COVID-19) infection, led to the growth of the demand for refrigerators in spring 2020 in the Russian cities in order to be able to keep more products at home. Local people usually combine different kind of fridges old Soviet, contemporary foreign and Russian, and self-made Chukchi fridges - different kind of frames and boxes made outside windows for keeping products. Moreover, they keep food in sheds and iron containers outside their flats and cottages. The use of a whole set helps them to avoid possible breaks in food supply.

Another strategy is centered on the autonomous production of food. Arctic is not a rigid space of a passive consumption. Local people creatively incorporate innovations into their way of life. They built a number of structures, which can function as a kind of food production infrastructure. During our fieldwork in Amguema we have observed numerous selfmade greenhouses which help local people to maintain their food security. Traditionally the spaces of the Arctic were not broadly employed for growing plants. This recent trend in Amguema is an attempt to fulfill a gap in vegetables' supply. Local Chukchis adapted the use of greenhouses from newcomers.

Transformation of things is a common way of dealing of the nomadic population with the material objects. Reindeer herders' movements imply continuous transformations of the dwellings and other material objects (Golovnev et al., 2018). The growing own vegetables in a greenhouse is a new trend of food security in the Arctic settlements. In Amguema the construction of the greenhouses became possible only due to the existence of abandoned buildings along the Iul'tinskaia road. These ruins, however, still full of life (Tsing, 2017: 21) for local people and serve as a storage of building materials and fuel. People use the wooden parts both to build and heat their greenhouses.

Local people produce their own smoked fish. They build small separate buildings they use as smokeries. In Amguema for this purpose people often employ old iron containers and sheds. They use woods from the pols of the old power line as fuel. In this sense, people extend the existing infrastructural projects by adding own structures to store and process food.

\section{Variety of tastes: perception of food}

The inhabitants of the Iul'tinskii district of Chukotka divide food into various categories: in addition to the common for the region classification of food into marine and tundra, people speak about Chukchi and Russian food, as well as about 'tundra' and 'state' (produced at slaughter centers) venison. Access to different types of food resources in different places is not equal. For instance, it is obvious that marine food is concentrated on the coast, and tundra food is produced by the reindeer herders in the tundra. People prepare particular types of food and associate them with particular places. As a result, the nutritional demands of local people create a need to establish a system of food circulation.

The idea of foreign food dates back to the time of the first contacts of Chukchis with Russians and Americans. V.G. Bogoraz described this situation in his monograph (Bogoraz, 1991). The serious restructuring of food habits took place as a result of the policy of Sovietization. Due to the spread of European products, new food processing technologies, and infrastructure changed the aesthetic perception of food by the members of local communities, which creatively incorporated numerous cultural and technological innovations. Today the diet of reindeer herders and hunters includes a large number of imported products called by the local people 'Russian' food. It does not mean the products are really Russian in their origin. Many products are part of contemporary local people's diet, but people associate them with the certain locality: the tundra or the village. As the reindeer herders say, "In the tundra we are missing Russian food, in the village we are missing Chukchi products." In the tundra, local people consume "Chukchi" food more frequently than in settlements. They apply the similar ethnic division into 'Russian' and 'Chukchi' to other material objects such as 
sledges (Golovnev et al., 2018: 93, 94), clothes and firewood. The quality of firewood is very important component for products taste. Therefore, in order to prepare food on the hearth some people prefer using local Chukchi firewood gathered locally brushwood instead of Russian or 'Ivan's firewood' (ivanovy drova) made from logs and planks, which were brought from the mainland.

Local informants say that they like the Chukchi food, they feel a sense of nostalgia while consume it and often contrast it with the Russian food, which, according to them, is not energetic enough and "leaves a person hungry". Thus, people in Amguema associate the Chukchi food with a sense of satiety and taste sensations familiar to them from childhood. In modern conditions, people maintain food exchange between different localities, which includes not only coastal and tundra food, but of the local Chukchi and imported Russian or European food.

The taste of food is a result of particular technological operations and it depends on a large number of components. The context or environment is an active agent of food production. Local people say that they differentiate the food prepared on fire in yarangas and on the electric stoves in cottages and flats. In many cases people cook the Chukchi food directly in their dwellings in the village, but, according to local residents, its taste would be inferior to tundra products. The taste of food is affected by the place where it is cooked. For example, a dried venison ( $k y k v a t o l ')$ made in a yaranga tastes differently from meat wilted in a cold hallway of a house in the village.

Local people incorporate numerous technological innovations into their way of life. The introduction of imported products was accompanied by the spreading of new food processing technologies. For example, earlier, during cold period of the year Chukchis used freezing and consumed a significant part of food frozen (Mikhailova, 2015: 108). They also actively employed the technology of fermentation and drying. However, the spreading of refrigerators and freezers made freezing one of the main technologies used to store food and people use it in any season.
Combining different technologies, local people try to keep the variety of tastes, which would not be available just through the distribution of products via the local stores. They employ a whole set of possibilities to create food of different tastes. Sharing a food, in this sense, means sharing of something exclusive with a particular story and "biography" (Kopytoff, 1986). This helps people to avoid the lack of tastes, which could be produced via the products obtained within the centralized food supply system. Therefore, people employ their knowledge and creativity to make a diversity of tastes, which become incorporated into the local system of food exchange. This strategy is not just a way to share memories, it is also a way to maintain the relations between the members of the local community. However, food exchange is not just a method of building local identity and a sense of solidarity. It creates an important food security mechanism of making additional stocks of products in order to be less dependent on the external supply.

\section{Infrastructure and food security strategies}

Local infrastructure is a result of a set of different development projects, which were carried out in different time, but today they all are present in local people's lives. In the context of food practices, the most important of them are the Iul'tinskaia road, the reindeer-slaughter center, apartment buildings and cottages in the villages. All these projects are an integral part of the daily practices of local people and affect the supply of the local community with products. In this way, they help people to maintain a sense of their food security.

The introduction of a new infrastructure affects the perception of food resources by local people. On the one hand, the emergence of additional opportunities for transportation, processing and storage of food allows them to organize the use of the resource. On the other hand, this inevitably affects the physical qualities of the products, because it changes technologies of their transportation and storage, transforms their condition and taste. Infrastructure changes food practices of local people and creates the possibility of emergence of new sources of food. For example, as mentioned above, 
the inhabitants of the Iul'tinskii district divide venison into 'tundra' and 'state'. This division was the result of the slaughter companies that spread during the Soviet period. A new reindeer-slaughter center was built near Amguema on $94 \mathrm{~km}$ of the Iul'tinskaia road. Previously, the special rituals always accompanied slaughter in the tundra and took place mainly during reindeer herders' feasts (Bogoraz, 1939). Contrary to the to the camps camps in tundra, slaughter at special centers does not contain this ritual component.

In Amguema reindeer slaughter takes place in fall. People send venison to Egvekinot, and then its main party goes to Anadyr. Small part of meat remains in the village, primarily to supply kindergarten and boarding school. Sometimes local people buy frozen meat at the refrigerator of the reindeer herding enterprise. At the same time, they consider that it has a very bad taste and low nutritional properties. In this regard, many of them try to avoid buying venison from the slaughter center, and prefer getting it from the tundra. Thus, people transport most of the slaughtered meat by the road to the seaport in Egvekinot and use water transport to deliver it to Anadyr. Tundra meat goes from reindeer herders' brigades mainly to Amguema, Nutepel'men, Vankarem and Egvekinot for consumption by local people.

Thus, the infrastructure development project, such as the building of the slaughterhouse as well as functioning of the reindeer herding enterprise and its commercial tasks generate the existing venison mobility channels. However, their existence became possible largely due to another project of the Soviet era - the Iul'tinskaia road. In other words, we can talk about a whole 'cascade' of projects, which give local people 'affordances' (Gibson, 1979, Ingold, 2000), providing the possibilities for implementing certain practices. In many respects, these possibilities appeared due to financial investments of the state. In case the state had not ensured the development of the infrastructure in the region, people would not be able to implement these practices (Etkind, 2020: 59).

If we consider the problem of food supply in Amguema in the historical perspective, we can conclude, that the very creation of this settlement, with the aim of transferring the nomadic population to sedentary life, created a need to transport venison from the tundra to the village. This type of supply became especially important since the products brought from the outside did not completely satisfy the needs of the local people.

The policy of sedentarization implied the construction of houses for reindeer herders and facilitated permanent pendulum migrations between camps in the tundra and the settlement, which also led to periodic changes in population density in the settlement and the tundra depending on the 'seasonal variations' of local people's activities (Mauss, 1979). Today people live in apartment buildings in Egvekinot, they live mostly in "Abramovich's cottages" in Nutepel'men and they use both block houses and cottages in Amguema. The new buildings have almost completely replaced the old wooden houses of the Soviet era. Several old houses are still in use in Nutepel'men.

New types of housing frame particular micro-mobility of local people - the movements of people within a settlement and its surroundings to satisfy their nutritional needs. For example, in the apartment buildings, people may face the stigmatizing of their eating habits by neighbors. In particular, this situation characterizes the district center, where many newcomers live. According to informants, in order not to disturb their neighbors by strong smell, they sometimes prefer short trips to the tundra to cook seal and walrus meat in the open air. In cottages, according to local people, which operate similarly to thermoses, some products are poorly preserved and cannot be prepared. In many cases, the thermal properties of new houses do not allow following traditional cooking technologies. For instance, seal fat may become rancid and spoiled if people keep it inside a cottage.

Therefore, it is not possible to prepare some Chukchi products inside the houses and flats and local people employ additional buildings for storage and cooking. They use containers, build sheds, as well as yarangas. From spring to summer some families construct their yarangas on the shore of the Amguema River, where they can cook. This food, according 
to them, is very different from what can be prepared on an electric stove in a house or an apartment. Moreover, the hearth in a yaranga serves as a mediator in relations between people, reindeer, the land, and the dwelling itself (Vaté, 2013: 192). Thus, local people prefer to cook food on the hearth in a yaranga or bonfire on the river bank to create the variability in the tastes of food and avoid cooking it exclusively by the use of the infrastructure, affordable in settlements.

\section{Conclusion}

On the one hand, various development projects, commercial initiatives and their material incarnations in the form of roads, buildings, slaughterhouses, cottages, flats and shops form people's needs in particular products. On the other hand, they may both hinder or contribute to the satisfaction of local people's food requests. In other words, the relations between these projects and the needs of people can be characterized by both intersection points and "gaps" that require active regulation by the local community. Moreover, each project can be embodied into the network of other initiatives, that leads to the formation of a whole "cascade" of projects. The reindeer herding enterprise, the slaughterhouse, the Iul'tinskaia road, and the seaport in Egvekinot, in their alliance, allow the export of local venison to the district and regional centers, as well as delivering products from the mainland to villages and reindeer herders' camps in the tundra.

The existence of the reindeer-slaughter center in Amguema stimulates people's reflec- tion on the taste of venison, and also affects their food strategies. Comparing of different tastes of meat by local people forms certain categories of venison, that creates new directions of product's transportation, implying the use of the existing roads. In a similar manner, the other infrastructure projects, such as, for example, rural shops and roads, function in a tandem. On the one hand, the road helps to establish the regular deliveries of expired goods from the district center to Amguema. On the other hand, local people, solve the problem of low quality of products and the lack of their variety in rural stores by making pendulum trips to Egvekinot. However, they would not be able to transport food autonomously without the Iul'tinskaia road, the functionality of which is supported by the state.

Thus, the changes of local people's and material objects' mobility led both to the formation of new food patterns, and to the change in the system of resources' distribution between the settlements of the Iul'tinskii district. All recent systemic changes became possible due to the integration of this transport facility in a series of other infrastructural state projects, ranging from the Northern Sea Route and the reindeer-slaughter center to power lines and trading bases, located along the highway. Therefore, the Iul'tinskaia road exists as an unfinished project, which functionality depends on the actions of numerous actors. In this context, the infrastructural incompleteness of the road, supplemented by other projects, contributes to its creative use by local people.

\section{References}

Afanas'eva, G.I., Simchenko, Iu.B. (1993). Traditsionnaia pishcha beregovykh i olennykh chukchei [Traditional Food of The Coastal and Reindeer Chukchis]. In Sibirskii etnograficheskii sbornik [Siberian ethnographic collection], 6 (1), 56-100.

Bogoras, W. (1904). The Chukchee. Material Culture. New York, Leiden: G.E. Stechert, E. J. Brill Ltd, $276 \mathrm{p}$.

Bogoraz, V.G. (1939). Chukchi. Religiia [Chukchis. Religion]. Part II. Leningrad: Izdatel'stvo Glavsevmorputi, $195 \mathrm{p}$.

Bogoraz, V.G. (1991). Material'naia kul'tura chukchei [Chukchi Material Culture]. Moscow: Nauka, Glavnaia redaktsiia Vostochnoi literatury, $224 \mathrm{p}$.

Chatwin, M.E. Socio-Cultural Transformations and Foodways in the Republic of Georgia. Commack, NY: Nova Sci, 1997, 221 p. 
Davydova, E.A., Davydov, V.N. (2018). Diet of the North-Eastern Chukotka Reindeer Herders: The Change of Food Autonomy Regime. In 5th International Multi-disciplinary Scientific Conference on Social Sciences and Arts SGEM 2018. Conference Proceedings, Vol. 5. Ancience Science, Issue 2.2. Anthropology, Archaeology, History, Philosophy, Medieval and Renaissance Studies. Sofia: STEF92 Technology Ltd., 27-34.

de Garine, I. (2004). Anthropology of Food and Pluridisciplinarity. In Researching Food Habits. Methods and Problems. Ed. by H. Macbeth, \& J. MacClancy. Berghahn books: New York, 15-27.

Douglas, M. (1966). Purity and Danger: An Analysis of Concepts of Pollution and Taboo. New York: Praeger, $188 \mathrm{p}$.

Douglas, M. (1974). Deciphering a Meal. In Myth, Symbol and Culture. New York: W.W. Norton and Co, 36-54.

Etkind, A. (2020). Priroda zla. Syr'e i gosudarstvo [Natural Evil: A Cultural History of Resources]. Moscow.: Novoe literaturnoe obozrenie, $590 \mathrm{p}$.

Gibson, J.J. (1979). The Ecological Approach to Visual Perception. Boston: Houghton Mifflin, 332 p.

Golovnev, A.V., Kukanov, D.A., Perevalova, E.V. (2018). Arktika: atlas kochevykh tehnologii [The Arctic: Atlas of Mobile Technologies]. St. Petersburg: MAE RAS, 352 p.

Goody, J. (1982). Cooking, Cuisine and Class: A Study in Comparative Sociology. Cambridge: Cambridge University Press, $253 \mathrm{p}$.

Goody, J. (1998). The Globalization of Chinese Food. In Food and Love: A Cultural History of East and West. London: Verso, 161-171.

Holtzman, J. (2006). Food and Memory. Annual Review of Anthropology, 35, 361-378.

Ingold, T. (2002). The Perception of Environment: Essays on Livelihood, Dwelling and Skill. London, New York: Routledge, $465 \mathrm{p}$.

Kopytoff, I. (1986). The Cultural Biography of Things: Commoditization as Process. In The Social Life of Things: Commodities in Cultural Perspective. Ed. by A. Appadurai. Cambridge: Cambridge University Press, 64-91.

Krupnik, I.I. (2000). Reindeer Pastoralism in Modern Siberia: Research and Survival During the Time of Crash, Polar Research, 19 (1), 49-56.

Kuznetsova, V.G. (1957) Materialy po prazdnikam i obriadam amguemskikh olennykh chukchei [The Materials on the Feasts and Rites of the Amguema Chukchi Reindeer Herders]. Sibirskii etnograficheskii sbornik II, 263-326.

Lentz, C. (ed.) (1999). Changing Food Habits: Case Studies from Africa, South America, and Europe. Amsterdam: Harwood Acad., 222 p.

Lévi-Strauss, C. (1969). Raw and the Cooked. New York: Harper \& Row, 387 p.

Lockwood, W.G., Lockwood, Y.R. (2000). Continuity and Adaptation in Arab American Foodways. In Arab Detroit: From Margin to Mainstream. Detroit: Wayne State Univ. Press, 515-559.

Matossian, M.K. (1989). Poisons of the Past: Molds, Epidemics, and History. New Haven, CT: Yale Univ. Press, $208 \mathrm{p}$.

Mauss, M. (1979). The Seasonal Variations of the Eskimo: A Study of Social Morphology. London: Routledge, 138 p.

Mayer, A. (1996). Caste in Indian Village: Change and Continuity 1954-1992. In Caste Today. Delhi: Oxford University Press, 32-64.

Mikhailova, E.A. (2015). Skitaniia Varvary Kuznetsovoi. Chukotskaia ekspeditsiia Varvary Grigor'evny Kuznetsovoi. 1948-1951 gg. [The Wanderings of Varvara Kuznetsova. Chukotka Expedition of Varvara Grigor'evna Kuznetsova. 1948-1951]. St. Petersburg: MAE RAN, 190 p.

Mintz, S. (1985). Sweetness and Power: The Place of Sugar in Modern History. New York: Penguin, $274 \mathrm{p}$.

Mintz, S. (1996). Tasting Food, Tasting Freedom. Boston: Beacon, 149 p.

Mintz, S., Du Bois, C. (2002). The Anthropology of Food and Eating. In Annual Review of Anthropology, 31, 99-119. 
Sutton, D. (2010). Food and Senses. In Annual Review of Anthropology, 39, 209-223.

Tsing, A.L. (2017). Grib na kraiu sveta: o vozmozhnosti zhizni na ruinakh kapitalizma [The Mushroom at the End of the World. On the Possibility of Life in Capitalist Ruins]. Moscow: Ad Marginem Press, 376 p.

Urry, J. (2012a) Mobil'nosti [Mobilities]. Moscow: Praksis, 576 p.

Urry, J. (2012b). Sotsiologiia za predelami obshchestva: Vidy mobil'nosti dlia XXI stoletiia [Sociology Beyond Societies: Mobilities for the Twenty-First Century]. Moscow: Izdatel'skii dom Vysshei shkoly ekonomiki, $336 \mathrm{p}$.

Urry, J. (2014). Offshoring. Cambridge: Polity Press, 212 p.

Vaté, V. (2013). Building a Home for the Hearth: An Analysis of a Chukchi Reindeer Herding Ritual. In About the Hearth: Perspectives on the Home, Hearth and Household in the Circumpolar North. New York; Oxford, 183-199.

Vdovin, I.S. (1965). Ocherki istorii i etnografii chukchei [Essays on the History and Ethnography of Chukchis]. Moscow-Leningrad: Nauka, 404 p.

Yamin-Pasternak, S., Kliskey, A., Alessa, L., Pasternak, I., and Schweitzer, P. (2014). The Rotten Renaissance in the Bering Strait: Loving, Loathing, and Washing the Smell of Foods with a (re) Acquired Taste. In Current Anthropology, 55 (5), 619-646.

Yamin-Pasternak, S., Schweitzer, P., Pasternak, I., Kliskey, A., Alessa, L. (2017). A Cup of Tundra: Ethnography of Thirst and Water in the Bering Strait. In Meanings and Values of Water in Russian Culture. London \& New York: Routledge, 117-136. 


\title{
Пути к существованию:
}

\section{инфраструктура и стратегии пищевой безопасности}

на Чукотке

\section{В.Н.Давыдов, Е.А.Давыдова}

Музей антропологии и этнографии

им. Петра Великого (Кунсткамера) РАН

Российская Федераиия, Санкт-Петербург

\begin{abstract}
Аннотация. Для отдаленных и труднодоступных арктических поселений чрезвычайно актуальной является проблема снабжения продуктами питания. Вследствие этого местные жители активно используют свои собственные стратегии распределения продовольствия. Они применяют альтернативные способы приобретения и сохранения продуктов питания в целях поддержания ощущения своей продовольственной безопасности посредством использования местной инфраструктуры, задействования сетей родственников и знакомых, а также применения технологий для самостоятельного производства, обработки и хранения продуктов. В статье описываются актуальные тенденции циркуляции пищевых ресурсов в Иультинском районе Чукотского автономного округа. Авторы рассматривают сложившуюся модель перераспределения продовольствия между окруженными тундрой и находящимися на побережье селами, оленеводческими стоянками, а также районным центром. Они анализируют влияние одного из крупнейших советских проектов на Чукотке - Иультинской трассы на практику обеспечения продовольственной безопасности местного населения. Появление новой инфраструктуры в регионе повлияло как на его мобильность, так и на восприятие пищи. В статье продемонстрировано, каким образом целый ряд различных государственных проектов и коммерческих инициатив влияют на формирование пищевых потребностей, но в то же время могут либо препятствовать, либо способствовать их удовлетворению. Отношения между инфраструктурными проектами и потребностями в продуктах питания имеют как точки пересечения, так и «разрывы», которые требуют активного регулирования со стороны членов местного сообщества и государства. В данном контексте местные жители являются активными агентами, креативно использующими имеющуюся в регионе инфраструктуру в целях поддержания своей пищевой безопасности.
\end{abstract}

Ключевые слова: Арктика, Чукотка, инфраструктура, пищевая безопасность, автономность, ресурсы, снабжение, антропология пищи, мобильность, оленеводство.

Работа выполнена за счет гранта Российского научного фонда (проект № 19-78-10002), проект «Питание в Российской Арктике: ресурсы, технологии и инновации».

Научное направление: 07.00.07 - этнография, этнология и антропология. 